\title{
Irrigation Investments in Romania. Size, Results, Efficiency (1965-1989)
}

\author{
Aurel LUP ${ }^{1 *}$, Liliana MIRON² , Indira Deniz ALIM ${ }^{3}$ \\ ${ }^{1}$ Department of Natural and Agricultural Science, Ovidius University of Constanta, 124 Mamaia \\ Boulevard, Constanta, Romania \\ ${ }^{2}$ Department of Natural and Agricultural Science, Ovidius University of Constanta, 124 Mamaia \\ Boulevard, Constanta, Romania \\ ${ }^{3}$ Department of Natural and Agricultural Science, Ovidius University of Constanta, 124 Mamaia \\ Boulevard, Constanta, Romania \\ *corresponding author, e-mail: lupaurel@yahoo.com
}

BulletinUASVM Horticulture 74(1) / 2017

Print ISSN 1843-5254, Electronic ISSN 1843-5394

DOI:10.15835/buasvmcn-hort:12368

\begin{abstract}
In Romania, more than 3 million hectares were equipped for irrigation, one of the greatest areas in Europe. The aim was represented by drought control and the intensification of agriculture, by increasing the yield per hectare. The financial effort was very important, i.e. over 10 million USD borrowed from the International Bank for Reconstruction and Development and from the World Bank. In order to accelerate the construction of irrigation systems and to save financial resources, the constructors renounced to several main parts of the system, such as drainage systems, measuring equipment, waterproofing the transport canals. Moreover, cheap and hand shifted equipment was used. The operation of the irrigation systems was also defective; there was insufficient electric power for pumping water, there were not enough fertilizers, pesticides and other yield factors. Thus, the yields per hectare were by $50-70 \%$ under the projected level. Economically, all the national irrigation systems produced loses instead of profits. At present, about 1.5 million hectares are pending rehabilitation, especially in the Danube Floodplain, which can be operated in profitability terms.
\end{abstract}

Keywords: investment in irrigation systems, intensification of agriculture, economic efficiency

\section{INTRODUCTION}

According to the specialists in the field, more than half of the arable land is periodically affected by drought, which is more or less severe, but sometimes catastrophic, like the drought of 19451946. In order to control the drought effects on crop yields, studies have been made since the beginning of the $20^{\text {th }}$ century, and there were made proposals in order to equip large areas for irrigation. Some of these studies took into account the equipment of approximately 2.7 million hectares, of which 0.5 million hectares would be irrigated by water from the Danube (Lup, 1997). However, in 1965, only 230 thousand hectares cultivated with vegetables and rice were actually irrigated. In the following
24 years, an area of nearly 2.9 million hectares of farmland would be equipped for irrigation. By the end of 1989, the area equipped for irrigation in Romania was represented by 3109.0 thousand hectares of farmland and 2931.0 thousand hectares of arable land, one of the largest areas equipped for irrigation in Europe (Lup, 1997).

This paper aims at describing the evolution of the areas equipped for irrigation between 1965 and 1989, the construction features of the irrigation systems from Romania, the operation of these systems, their influence on the agricultural yield, and finally, the efficiency of irrigations on the technical and economic performances of agriculture, in the second half of the $20^{\text {th }}$ century 
(Lup, 1997). The expansion of irrigations on almost a third of the country's arable land aimed both at controlling drought and at intensifying the agricultural yield, taking into account its extensive nature, compared to the agriculture of the developed countries in Western Europe.

\section{MATERIAL AND METHOD}

The most numerous sources used are statistical data. The authors monitored the evolution of the areas equipped for irrigation, both from the official statistical yearbooks and from the operative statistical data provided by the General Economic Bureau for Land Reclamation and Agricultural Constructions (DGEIFCA), i.e. the coordinator, constructor and administrator of all land reclamation works in Romania. The same source was used for the extraction of the data on investments (equipped areas, characteristics, technical and economic parameters).

The data on the technical and economic results obtained by the beneficiary (agricultural units)

Tab.1 Irrigation development in Romania

\begin{tabular}{cccc}
\hline \multirow{2}{*}{ Years } & \multicolumn{2}{c}{$\begin{array}{c}\text { Equipped surface } \\
\text { - thousand ha - }\end{array}$} & $\begin{array}{c}\text { Ratio of the surfaces equipped } \\
\text { for irrigation from arable lands + } \\
\text { vineyards + orchards } \\
\%\end{array}$ \\
\cline { 2 - 4 } & Agricultural & Arable & 0.1 \\
\hline 1938 & 15.4 & 15.4 & 0.4 \\
\hline 1950 & 42.5 & 42.5 & 0.9 \\
\hline $1955 W$ & 93.1 & 92.1 & 1.9 \\
\hline 1960 & 199.7 & 197.2 & 2.2 \\
\hline 1965 & 229.9 & 220.4 & 6.3 \\
\hline 1970 & 714.6 & 686.3 & 14.0 \\
\hline 1975 & 1437.3 & 1369.8 & 21.2 \\
\hline 1980 & 2221.8 & 2125.1 & 27.1 \\
\hline 1985 & 2873.9 & 2723.2 & 31.0 \\
\hline 1990 & 3109.0 & 2931.9 & \\
\hline
\end{tabular}

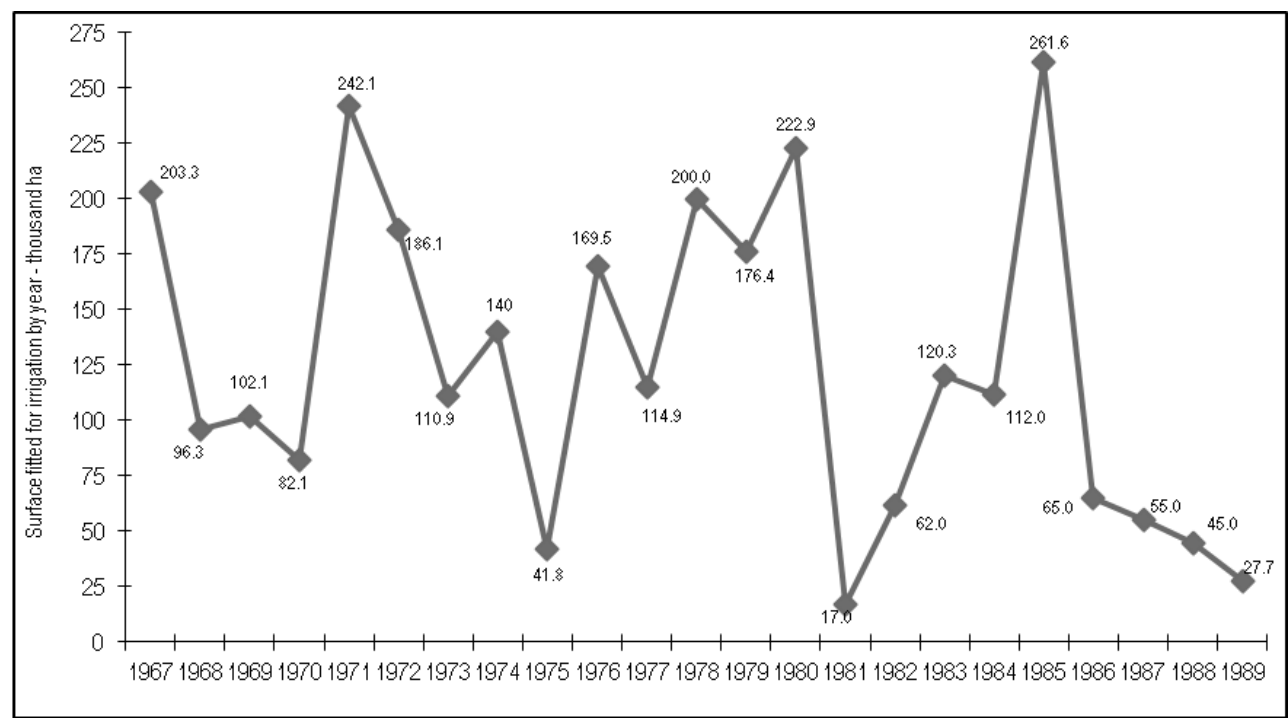

Fig.1. Areas equipped for irrigation, anually, in Romania 
were taken from their balance statements (AGR 1). The calculations regarding the results grouped by counties, regions or at national level belong to the authors and were performed by methods specific to economic research - collection, selection, grouping, elaboration and conclusions.

\section{RESULTS AND DISCUSSIONS}

As regards the evolution of the areas equipped for irrigation, it is noteworthy that, in 1965, Romania had 230 thousand irrigated hectares, i.e. only $2.2 \%$ of the arable land. In the same year, the ratio of the arable land equipped for irrigation was $22.1 \%$ in Italy, $20.9 \%$ in Bulgaria, $14.7 \%$ in Greece, $11.2 \%$ in Spain; the European average was 6.6\% (Lup and Miron, 2015). This lagging would be recovered in a short time period. Annually, areas between 17 thousand hectares (1981) and 261.6 thousand hectares (1985) were brought into service, the annual mean being approximately 120 thousand hectares (Tab. 1, Fig. 1). Over 3,100 thousand hectares were equipped for irrigation, according to four successive programs; the last one (1983) stipulated that 5,500 thousand hectares would be equipped for irrigation by 1989 . The irrigation equipments were concentrated in nine counties from the Danube Floodplain and Dobrudja, with the Danube as the water source for the irrigation of over $3 / 4$ of the equipped surface (Lup, 1997).

In teWrms of the investments in irrigations, over the last three decades of planned agriculture, more than 6,650 billion lei or 643 billion US dollars were invested, according to the studies of the Institute for Agrarian Economy and the Central Bureau of Statistics. Of this sum, the hydroameliorative works received growing amounts, beginning with $7.5 \%$ in 1961-1965, and reaching more than $35 \%$ in $1986-1989$, the mean of the three decades being $32 \%$.

Converted into the currency of the time, the investments in hydro-ameliorative works amounted to 46 billion US dollars, according to evaluations of the World Bank. It is noteworthy that these sums represent the ensemble of land reclamation works, including particularly the embankment and drainage works that proceeded the edification period of the national irrigation systems.

The calculation of the investments in irrigation represents a difficult endeavor, mainly because numerous projects involved complex works that included both the actual equipment for irrigation and works for the control of excessive humidity (including drainage), anti-erosion works and others. For example, in Frunzaru irrigation system (Olt and Teleorman counties), from the total investment of 48,864 lei/ha, the irrigations represented $75.5 \%$ of the investment, the drainage works - $15.4 \%$, the erosion control works $-2.6 \%$ and the other works accounted for the remaining $6.7 \%$. Secondly, the execution period of an irrigation system was very long, and, in the meantime, the investment per area unit was increasing continuously. In Sinoe system (Constanta county), a first area of 57,152 hectares was brought into service in 1975, with a specific investment of 15,687 lei/ha. Then, an expansion of 4,880 hectares was planned for 1984, with a specific investment of 53,950 lei/ha (Lup, 1997). Thirdly, the sums in lei had to be converted, for compatibility, into US dollars, in exchange rates, which were also different from one period to another.

An evaluation of the irrigation investments was performed due to the head of the state himself. In the text of the last program on the development of land reclamation works elaborated under Nicolae Ceausescu's direct supervision, in 1983, he declared that: "The state's efforts in terms of land reclamation will be reflected by more than 27 billion lei invested in irrigation works, over 9 billion lei invested in drainage works, 7 billion lei invested in soil erosion control works and 18 billion lei invested in the performance of a complex volume of works aimed at the protection against floods and water accumulation".

Evaluated in terms of the currency exchange rate at the time, the land reclamation costs summed up, by the end of 1982, to approximately 12.2 billion US dollars, of which 5.45 billion US dollars were invested only in irrigations. After 1980, the investment in the equipment of a hectare for irrigation was at least 50 million lei. Thus, 36.45 billion lei or 8.7 billion US dollars were invested in order to equip 729 thousand hectares for irrigation, between 1983 and 1989; this sum was added to the 5.4 billion US dollars invested before 1983, reaching a total of 14.1 billion lei, only for irrigations.

The conclusion regarding the investments in irrigations is that they had absolute priority within the ensemble of the investments in land reclamation works and that the sums invested in irrigations exceeded Romania's entire external 
debt, accumulated over the last decade of totalitarian regime. This is explained by the fact that a lot was expected from irrigations. According to some calculations performed by the author, the additional yield capacity of the irrigated areas represented the equivalent of over seven million tons of cereals per year (Lup, 1997). However, over the last five years of the regime (1985-1989), Romania exported, according to official statistics, less than 2.2 million tons of cereals.

Regarding the characteristics of the irrigation systems in Romania, according to older studies, Romania's irrigation potential was estimated at 5,341 thousand hectares, of which 5,029 thousand hectares (i.e. 94.2\%) were going to be irrigated from inner rivers, while 312 thousand hectares (i.e. 5.8\%) from the Danube, namely the Danube Floodplain and the Danube Delta. Subsequently, the Danube was preferred as a water source, so that almost $83 \%$ of the equipped areas were irrigated from the river by pumping water upwards to heights cumulated at over $200 \mathrm{~m}$ (Lup, 1997). This first characteristic entails the second, i.e. the high consumption of electricity for water pumping. Over half of the equipped areas required an electricity intake exceeding $700 \mathrm{kWh}$ for the irrigation of one hectare (Fig. 2).
The irrigation systems in Romania are also characterized by size. In a reference system, in which the areas equipped for irrigation that exceed 500 hectares are considered "large systems", we can say that, practically, everything that was built in our country in this field is part of the so-called "gigantic systems" category.

According to a classification used in the literature from our country, the areas between 25,000 and 50,000 hectares are considered large hydro-technical systems; medium ones have between 10,000 and 25,000 hectares and small ones have less than 10,000 hectares.

The gigantic dimensions of the irrigation systems required the construction of adduction and distribution canals with a total length of almost $11,000 \mathrm{~km}$, mostly non-waterproofed or waterproofed unsatisfactorily, which triggered water losses ranging from $30 \%$ to $60 \%$ of the water pumped from base stations. Built in a floating system on the Danube, the 54 base pumping stations (Tab. 2) represented a significant weight in terms of irrigation investments.

Regarding the property structure of the hydro-ameliorative systems, in terms of the property over the lands where the irrigation systems are located (canals, pumping stations, artworks), before 1989, these were used by builders without

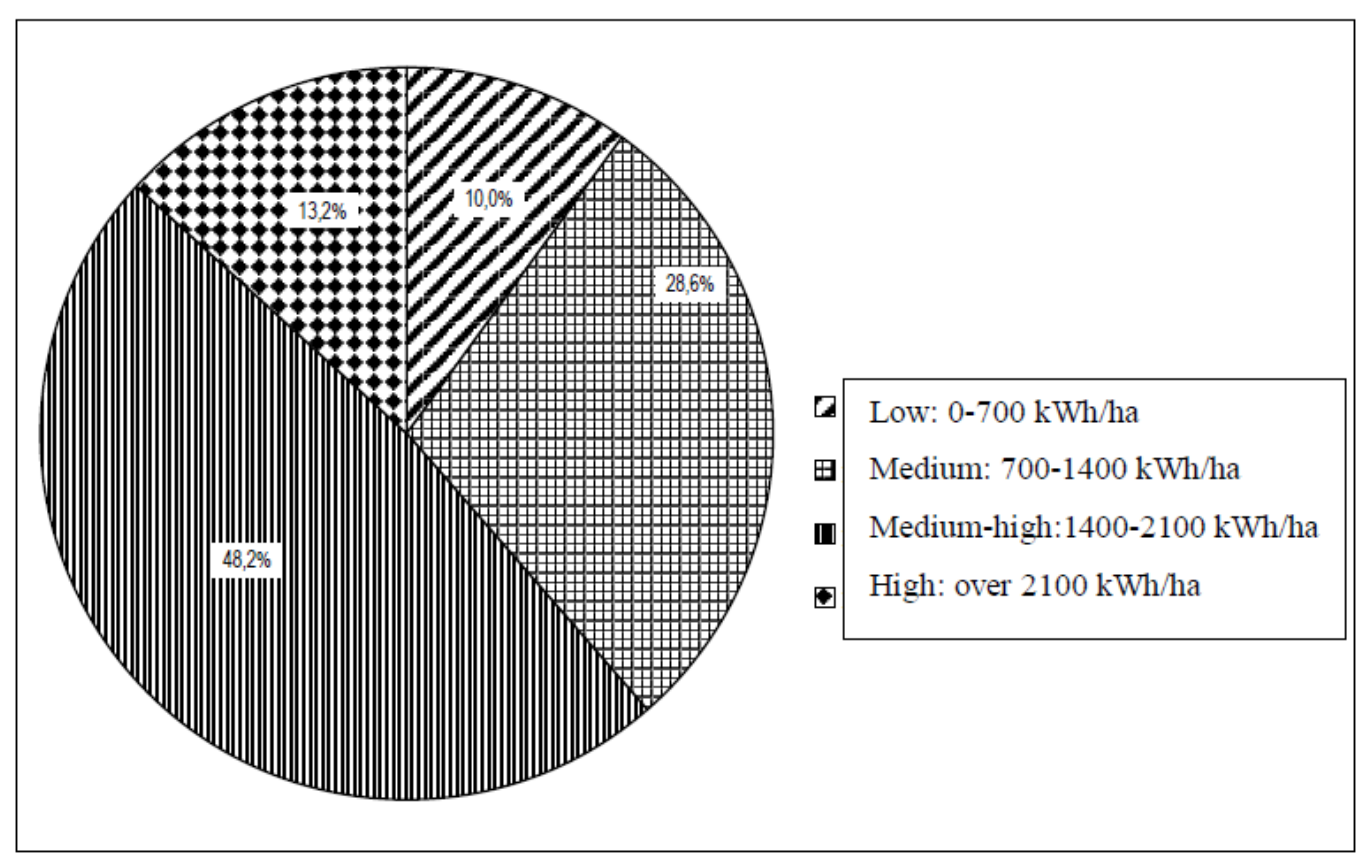

Fig. 2. Classification of the areas equipped for irrigation by the electricity intake required for the irrigation of one hectare, with an average structure of crops (Source: Processed according to R.A.I.F. data) 
Tab.2. Classification of the main hydro-technical systems in Romania, by size

\begin{tabular}{lccc}
\hline \multicolumn{1}{c}{ Size class } & $\begin{array}{c}\text { Number of } \\
\text { systems }\end{array}$ & $\begin{array}{c}\text { Average } \\
\text { surface } \\
\text { ha }\end{array}$ & $\begin{array}{c}\text { Ratio in terms } \\
\text { of equipped } \\
\text { surface } \\
\%\end{array}$ \\
\hline Gigantic systems: over 100000 ha & 4 & 126139 & 21.5 \\
\hline Very large systems: $50000-100000$ ha & 13 & 72954 & 32.4 \\
\hline Large systems: $25000-50000$ ha & 18 & 37176 & 22.9 \\
\hline Medium systems: $10000-25000$ thousand ha & 29 & 16653 & 16.5 \\
\hline Small systems: sub10000 ha & 39 & 5018 & 7.6 \\
\hline Total no/mean & $\mathbf{1 0 4}$ & $\mathbf{2 8 1 4 4}$ & $\mathbf{1 0 0 . 0}$ \\
\hline
\end{tabular}

Source: Data according to ISPIF

Tab. 3. The ratio of the adduction and watering equipment within the total investment, in some hydroameliorative systems located in various areas of the country

\begin{tabular}{lcc}
\hline \multirow{2}{*}{\multicolumn{1}{c}{ Hydro-technical system }} & \multicolumn{2}{c}{ Ratio within the investment value \% } \\
\cline { 2 - 3 } & Adduction & Watering equipment \\
\hline Borcea de Sus (Călăraşi county) & 4.9 & - \\
\hline Borcea de Jos (Ialomița county) & 13.5 & 10.9 \\
\hline Carasu (Constanța county) & 29.3 & 15.3 \\
\hline Ipotești (Olt county) & 47.7 & 9.0 \\
\hline Grădiștea-Făurei (Brăila county) & 54.1 & 9.7 \\
\hline
\end{tabular}

Source: Processing according to I.S.P.I.F. data.

taking the owners into account. However, after 1990, it was discovered that the National Agency for Land Reclamation had located investment objectives on lands that it did not own. The problems arose especially after 2000, when the restoration of lands to their former owners required that the lands of both agricultural cooperatives and state agricultural enterprises be attacked. It seems that this situation created (and it is still creating) difficulties in the process of transfer of the irrigation infrastructure to OUAI (The Organization of Water Users for Irrigations).

Another aspect connected to the property structure is the dissociation of the investment in the equipment itself and in the watering equipment, the latter belonging exclusively to the beneficiary (Tab. 3).

The reduced ratio of the watering equipment is explained first by the designer's option for less performing equipment, generally, with manual input, although it was stated that the equipments were designed according to the technical requirements of the time. Another explanation is the fact that, initially, at least one third of the area was going to receive surface irrigation (inbetween the furrows), a method that required minimal investment (Lup, 1997). Regardless of the financing sources, the state was the main investor in land reclamation works and, consequently, the owner of fixed facilities. In terms of irrigation equipments, the property structure - state-owned or private - also derives from the organization and exploitation manner of that investment. Thus, the water catchment points, the pumping and repumping stations, the adduction and most of the distribution network, including the pressurization stations, were owned and exploited by the state through its specialized units from each county. 
A part of the investment, represented by the last ramifications of the distribution network, as well as a part of the mobile watering system were supported financially by the state-owned or cooperative agricultural units and, thus, were owned by them. The ratio of the agricultural beneficiary was between $30 \%$ and $40 \%$ of the specific investment, depending on the type of equipment and the structure of the watering system. At the beginning, for the massive equipment with sprinkler irrigations by means of thermal pumping aggregates, the agricultural units' investment increased considerably. The consequence of introducing watering equipment with a more advanced mechanization or automation degree also increased the agricultural producers' contribution to the investment structure and, consequently, to the property structure.

As regards the economic efficiency of irrigation investments at the project stage, two political imperatives - the equipment of a large area in a short time period and maintaining the specific investments to a very low level - forced the designers to accept some very optimistic technical and economical exploitation parameters. Very high average yields associated with underevaluated expenses - kept within the limits of extreme avarice - ensured the threshold of economic efficiency, able to sustain the two objectives mentioned above.

Over time, the profitability level required for the promotion of projects was kept by planning larger and larger yields per hectares during the exploitation period of the hydro-technical systems. This is how the main indicators of economic efficiency evolved at project level during the maximum development period of irrigations equipment (Tab. 4).

It was considered appropriate to dissociate this period into two segments, i.e. one before 1981 and the other after 1981, characterized by a system of increased prices for agricultural products (Decree 393/XII.1980). It is noteworthy that this price increase for contracting and acquiring most products did not influence positively the estimated economic efficiency, as the profitability rate decreased to $53.8 \%$ in the second period, compared to $62.1 \%$ before 1981 . The explanation consists of an increase in exploitation expenses, as well as in the specific investments, compared to yield values (Lup, 1997).

Regarding the economic efficiency of the investments in irrigations in the exploitation stage (Tab.5), under non-irrigation conditions, in both design periods (1970-1972 and 1983-1985) the agricultural yield was efficient (Lup, 2014).

Tab.4. Evolution of the estimated economic efficiency parameters of irrigation equipment, in terms of work design and performance period (average data)

\begin{tabular}{|c|c|c|c|c|c|}
\hline \multirow[b]{2}{*}{ Specification } & & \multirow{2}{*}{$\begin{array}{c}\text { U/M } \\
\text { Before } \\
1981 \\
\end{array}$} & \multicolumn{2}{|c|}{ Design period } & \multirow{2}{*}{$\frac{1981-1989}{<1981 \%}$} \\
\hline & & & $\begin{array}{c}\text { After } 1981 \\
(1981-1989)\end{array}$ & & \\
\hline Yield value before the equipment for irrigation & & lei/ha & 3714 & 7605 & 204.7 \\
\hline Yield value after the equipment for irrigation & $”$ & 9077 & 17724 & 193.1 & \\
\hline Increase in the yield value & $”$ & 5363 & 10119 & 185.2 & \\
\hline Expenses before the equipment for irrigation & $”$ & 2344 & 5643 & 240.7 & \\
\hline Expenses after the equipment for irrigation & $”$ & 5600 & 11527 & 209.6 & \\
\hline Additional expenses & 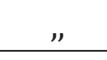 & 3256 & 5884 & 186.4 & \\
\hline $\begin{array}{l}\text { Net income before the equipment for } \\
\text { irrigation }\end{array}$ & $"$ & 1370 & 1962 & 143.2 & \\
\hline Net income after the equipment for irrigation & $”$ & 3477 & 6197 & 168.5 & \\
\hline Additional net income & ” & 2107 & 4255 & 183.6 & \\
\hline Specific investment & $”$ & 17330 & 45800 & 264.3 & \\
\hline Recovery duration & years & 8.2 & 10.8 & 131.7 & \\
\hline
\end{tabular}

Source: Processed according to I.SP.I.F. data 
Tab. 5. Evaluation of the economic efficiency of the investments in irrigations, in the exploitation stage, in some hydro-technical systems in Constanta county (lei/ha)

\begin{tabular}{|c|c|c|c|}
\hline \multirow[t]{2}{*}{ Specification } & \multicolumn{3}{|c|}{$\begin{array}{l}\text { General efficiency of irrigations } \\
\text { (systems + agricultural units) }\end{array}$} \\
\hline & Yield value & Yield expenses & Net income \\
\hline \multicolumn{4}{|c|}{ Designs for 1970-1972 } \\
\hline Basic period, no irrigations (1967-1970) & 4690 & 3043 & 1647 \\
\hline Designs in Carasu complex & 9063 & 5585 & 3478 \\
\hline Mean 1985-1987 (accomplished) & 8155 & 10958 & -2803 \\
\hline Accomplished compared to the basic period \% & 173.8 & 360.1 & - \\
\hline Accomplished compared to the project $\%$ & 90.0 & 196.2 & - \\
\hline \multicolumn{4}{|c|}{ b) Designs for $1983-1985$} \\
\hline Basic period, no irrigations (1967-1970) & 4190 & 3178 & 1012 \\
\hline Designs in the systems: Harsova, Sinoe, Topalu & 13279 & 9146 & 3133 \\
\hline Mean 1985-1987 (accomplished) & 4456 & 8320 & -3864 \\
\hline Accomplished compared to the basic period \% & 106.3 & 261.8 & - \\
\hline Accomplished compared to the project $\%$ & 33.6 & 91.0 & - \\
\hline
\end{tabular}

Source: Processed according to data from I.SP.I.F., I.E.E.L.I.F. and agricultural units in the area

The lower profit obtained in the second half of the design stage is explained by the reduced fertility of the soils from the irrigation systems of Harsova, Sinoe and Topalu, compared to the fertility of the soils from Carasu system. However, in the exploitation stage, in both design periods, the agricultural yield was inefficient. During the first design period (1970-1972), the yield per hectare increased by $73.8 \%$, compared to the period prior to the equipment for irrigation (1967-1970) and it is closer to the estimated level (90\%). Instead, the additional technological expenses increased by $260.1 \%$, compared to the base period, when no irrigation was performed (1967-1970), and by $96.2 \%$, compared to the estimated level; therefore, the agricultural units registered losses instead of profits (-2803 lei/ha).

The unsatisfactory economic results obtained in the exploitation stage of the irrigation systems are a consequence of the fact that the yields per hectare were considerably below the estimated level, while the additional technological expenses for irrigations increased too much, compared both to the base period (without irrigations) and to the estimated level (1).

\section{CONCLUSIONS}

Between 1965 and 1989, an area of three million hectares was equipped for irrigation in order to control the drought that affected a large area of the Romanian agricultural land, but also for the purpose of technological intensification, given that the yield per hectare was one of the smallest in Europe.

The investments in irrigations were made with enormous financial efforts, based on external loans, compatible or even larger than those from the industry, thus contributing to running into national debt and to the need for extreme austerity measures in order to pay them.

By directing the resources, primarily in order to equip larger and larger areas for irrigation, and by neglecting the allocation of the resources required for the rational exploitation of irrigation systems, technical and economical results below estimations were obtained.

Due to flawed policies in terms of the distribution of resources, the investments in irrigations had an insignificant impact on drought and on the intensification of the vegetal yield.

In Romania, more than 3 million hectares were equipped for irrigation, i.e. a third of the arable land, in order to combat drought and to increase the yield per hectare. The foreign specialists estimated that half of this area would have been sufficient. The investments in irrigations cost over 10 million USD, borrowed from foreign banks. The payment of debts triggered massive exports of raw food and severe austerity measures for the population. The investments were oriented 
prioritarily towards the increase of the area equipped for irrigation, neglecting the resources necessary to their operation, such as the electric power needed in order to pump the water, fertilizers and other inputs. Consequently, the irrigations had an insignificant impact on the fight against drought and on the increase of the yield per hectare.

\section{REFERENCES}

1. Lup A (1997). Irigaţiile în agricultura României. Ed Agris, București.

2. Lup A (2014). Agricultura socialistă a României. Ed. Ex Ponto, Constanţa.

3. Lup A, Miron Liliana (2015). Management of the Irrigation Systems in Romania, between 1990-2014. Studies, Projects, Strategies. Scientific Papers Series Management, Economic Engineering in Agriculture and Rural Development Vol. 15(2):203-212. 